\title{
HUBUNGAN TINGKAT PENGETAHUAN PUTRA KELAS I DAN II TENTANG BAHAYA MEROKOK TERHADAP PERILAKU MEROKOK DI SLTP NEGERI 4 SUNGAI PENUH
}

\author{
Yosep Andri Putra \\ Akademi Keperawatan Bina Insani Sakti \\ Email Korespondensi: andri.andriputra@gmail.com \\ Disubmit: 28 Januari 2022 Diterima: 31 Januari 2022 Diterbitkan: 03 Februari 2022 \\ DOI: https://doi.org/10.33024/mnj.v5i2.5995
}

\section{ABSTRACT : THE RELATIONSHIP BETWEEN KNOWLEDGE LEVELS OF MALE STUDENTS IN CLASS I AND II ABOUT THE DANGERS OF SMOKING ON SMOKING BEHAVIOR AT SLTP NEGERI 4 SUNGAI PENUH}

Backround: Smoking is a habit that is commonly encountered in everyday life. Smoking either actively or passively harms the body. The World Health Organization (WHO) reports that cigarette consumption in Indonesia ranks 5 th in cigarette consumption in the world after China, the United States, Japan and Russia. Data from the results of statistical reports on the number of smokers 1.35 billion people with cigarette consumption in Indonesia reaching 215 billion cigarettes per year. The prevalence of smokers in Indonesia is $57.2 \%$ in men and $5.1 \%$ in women. Data obtained by active smokers in Jambi Province reached 22.9 percent. Lack of knowledge of adolescents about smoking will affect or have an impact on their attitudes and behavior, so that adolescents tend to consume cigarettes. Smoking behavior is very concerning, every time we encounter people of various ages, especially teenagers.

Purpose: The purpose of this study was to determine the relationship between the level of knowledge of male students in grades I and II about the dangers of smoking on smoking behavior in SLTP Negeri 4 Sungai Penuh.

Method: This study uses a descriptive analytical design with a cross sectional approach which was carried out at SLTP Negeri 4 Sungai Penuh as many as 32 respondents and data collection using a questionnaire. Data processing in the study began with editing, coding, entry, tabulating, and cleaning then analyzed by univariate and bivariate with the chis-square test.

Result: The results of this study obtained 20 (62.5\%) respondents with low knowledge and 17 (53.1\%) respondents with poor smoking behavior. Based on the results of statistical tests there is a relationship between knowledge and smoking behavior with $p$-value $=0.035$.

Conclusion: The conclusion is that there is a relationship between the level of knowledge of male students in grades I and II about the dangers of smoking on smoking behavior in SLTP Negeri 4 Sungai Penuh.

Keywords: Knowledge of the dangers of smoking, smoking behavior 
INTISARI : HUBUNGAN TINGKAT PENGETAHUAN PUTRA KELAS I DAN II TENTANG BAHAYA MEROKOK TERHADAP PERILAKU MEROKOK DI SLTP NEGERI 4 SUNGAI PENUH TAHUN 2021

Pendahuluan: Merokok merupakan salah satu kebiasaan yang lazim ditemui dalam kehidupan sehari-hari. Merokok baik secara aktif maupun pasif membahayakan tubuh. World Health Organization (WHO) melaporkan bahwa konsumsi rokok di Indonesia menduduki peringkat ke-5 dalam konsumsi rokok di dunia setelah China, Amerika Serikat, Jepang dan Rusia. Data dari hasil laporan statistik jumlah perokok 1.35 miliar orang dengan konsumsi rokok di indonesia mencapai 215 milyar batang pertahu. Prevalensi perokok di Indonesia adalah 57,2 \% pada laki laki dan 5,1\% pada perempuan. Data yang diperoleh perokok aktif di Provinsi Jambi mencapai angka 22,9 persen. Kurangnya pengetahuan remaja tentang rokok akan berpengaruh atau berdampak kepada sikap dan perilakunya, sehingga remaja cenderung untuk menkonsumsi rokok. Perilaku merokok sangatlah memprihatinkan, setiap saat kita menjumpai dimasyarakat dari berbagai usia terutama remaja.

Tujuan: Tujuan penelitian ini adalah diketahui adanya hubungan tingkat pengetahuan siswa putra kelas I dan II tentang bahaya merokok terhadap perilaku merokok di SLTP Negeri 4 Sungai Penuh.

Metode: Penelitian ini menggunakan desain Deskriptif Analitik dengan pendekatan cross sectional yang dilakukan di SLTP Negeri 4 Sungai Penuh sebanyak 32 responden dan pengumpulan data menggunakan kuesioner, Pengolahan data dalam penelitian dimulai dengan editing, coding, entry, tabulating, dan cleaning kemudian di analisa secara univariat dan bivariat dengan uji chis- square.

Hasil: Hasil penelitian ini diperoleh $20(62,5 \%)$ responden yang berpengetahuan rendah dan $17(53,1 \%)$ responden perilaku merokok kurang baik. Berdasarkan hasil uji statistik ada hubungan antara pengetahuan dengan perilaku merokok dengan nilai pvalue $=0,035$.

Kesimpulan: Kesimpulan bahwa adanya hubungan tingkat pengetahuan siswa putra kelas I dan II tentang bahaya merokok terhadap perilaku merokok di SLTP Negeri 4 Sungai Penuh.

Kata Kunci: Pengetahuan bahaya merokok, perilaku merokok

\section{PENDAHULUAN}

Rokok adalah hasil olahan tembakau terbungkus termasuk cerutu atau bentuk lainnya yang dihasilkan dari tanaman Nicotiana tabacum, Nicotiana rustica dan spesies lainnya atau sintetisnya yang mengandung nikotin dan tar dengan atau tanpa bahan tambahan. Merokok merupakan salah satu kebiasaan yang lazim ditemui dalam kehidupan sehari-hari. Merokok baik secara aktif maupun pasif membahayakan tubuh, (Umi Istiqomah, 2003).

World Health Organization

(WHO) melaporkan bahwa konsumsi rokok di Indonesia menduduki peringkat ke-5 dalam konsumsi rokok di dunia setelah China, Amerika Serikat, Jepang dan Rusia. Data dari hasil laporan statistik jumlah perokok 1.35 miliar orang dengan konsumsi rokok di indonesia mencapai 215 milyar batang pertahun (Gigih Firman Hartono, 2013 : 3). 
Di Indonesia, ada 57.000 jiwa meninggal setiap tahun akibat merokok atau 158 jiwa meninggal setiap hari akibat merokok. Selain itu, terdapat 85 juta perokok berat di Indonesia dan 1112 juta perokok akan meninggal. (Umi Istiqomah, 2003 : 22).

Prevalensi perokok di Indonesia adalah $57,2 \%$ pada laki laki dan $5,1 \%$ pada perempuan. Data yang diperoleh perokok aktif di Provinsi Jambi mencapai angka 22,9 persen. Bahkan dalam sehari 158.928 batang rokok yang dihisap dari jumlah itu Kabupaten Kerinci/kota sungai penuh menduduki peringkat tertinggi dengan jumlah 16.320 batang rokok yang dihisap, disusul Batanghari 15.936 batang dan Merangin 15.490 batang. (Riset Kesehatan Dasar, 2010).

Pusat penelitian Kesehatan Universitas Indonesia telah melakukan beberapa survey mengenai kebiasaan merokok. Salah satu survey pada tahun 2011 menemukan angka prevalensi merokok dikalangan penduduk usia 20 tahun keatas di Jakarta dan Sukabumi mencapai $68 \%$ dikalangan laki-laki, dan $8 \%$ perempuan (Gigih Firman Hartono, $2013: 3$ ).

Dalam Asap rokok mengandung kurang lebih 4000 bahan kimia yang diantaranya beracun dan dapat menyebabkan kanker bagi tubuh. Beberapa zat yang sangat berbahaya yaitu nikotin, tar dan karbonmonoksida (Ali Ma'ruf, 2015 : 17).

Ada beberapa permasalahan pada remaja antara lain kurangnya pengetahuan tengan rokok. Kurangnya pengetahuan remaja tentang rokok akan berpengaruh atau berdampak kepada sikap dan perilakunya, sehingga remaja cenderung untuk menkonsumsi rokok. Perilaku merokok sangatlah memprihatinkan, setiap saat kita menjumpai dimasyarakat dari berbagai usia terutama remaja. Masa remaja merupakan masa dimana seorang individu mengalami peralihan dari satu tahap ke tahap selanjutnya dan mengalami perubahan baik emosi, tubuh, minat, pola perilaku. Para remaja sekarang sering kali menganggap enteng dengan kesehatan. Mereka hanya memikirkan apa yang akan membuat senang, seperti rokok (Gigih Firman Hartono, $2013: 1$ ).

Penelitian yang dilakukan oleh World Health Organization dan koordinasinya berasal dari University of Bergen di Norwegia meneliti di Spanyol lebih dari $60 \%$ anak-anak telah mencoba merokok sekitar usia 15 tahun, dan hampir sepertiganya akan menjadi perokok harian sebelum berusia 18 tahun sampai akhirnya menjadi pecandu rokok (Umi Istiqomah, $2003: 2-3$ ).

Dari hasil penelitian di Indonesia, ada $31 \%$ mulai merokok di usia 10-17 tahun, dari Medan dilaporkan banyak dijumpai perokok anak-anak usia sekolah dasar. Di Jakarta Selatan di antara anak umur 12-18 tahun, $80 \%$ nya telah menjadi perokok. (Umi Istiqomah, $2003 \mathrm{hal}: 2$ ) Menurut data tahun 2004 yang dikeluarkan Global Youth Tobacco Survey (GYTS), dari 2074 responden pelajar Indonesia usia 15-20 tahun, $43,9 \%$ mengaku pernah merokok. Sebanyak $11,8 \%$ pelajar pria dan $3,5 \%$ pelajar wanita menganggap merokok akan menambah teman, sementara $9,2 \%$ pelajar pria dan $2,4 \%$ pelajar wanita menganggap merokok akan membuat mereka terlihat lebih atraktif (Andika Sulistiawan, $2010: 2$ ).

Berdasarkan penelitian yang dilakukan oleh Yudianto (2005) terhadap 12 orang pelajar STM/SMK 
Muhammadiyah 01 Kepanjen, 8 orang diantaranya $(66,7 \%)$ merokok, dan 4 orang $(33,3 \%)$ tidak merokok. Dari 8 orang yang suka merokok, 5 orang diantaranya $(62,5 \%)$ mengatakan menghabiskan rokok sekitar 10-19 batang per hari, 3 orang $(37,5 \%)$ merokok 1-9 batang per hari. Sebanyak 4 orang $(50 \%)$ dari remaja ini menganggap merokok sebagai kebutuhan, 6 orang $(75 \%)$ tahu tentang bahaya merokok namun mengatakan tidak takut merokok (Andika Sulistiawan, $2010: 3$ ).

Survey awal yang dilakukan di SLTP Negeri 4 Sungai Penuh, peneliti melakukan wawancara terpimpin dengan 10 orang responden. 4 orang mengatakan tahu tentang bahaya merokok dan 6 diantaranya tidak tahu tentang bahaya merokok. Jika remaja sudah kecanduan rokok, maka bisa atau tidak bisa harus mendapatkan apa yang dicari. Sehingga remaja mau mengorbankan apa saja yang dimiliki jika punya, dan jika tidak punya mereka akan nekad melakukan tindakan yang merugikan orang lain, seperti mencuri, jambret, merampok, bahkan memperkosa. Kalau sudah demikian biasanya dibarengi dengan penganiayaan terhadap korban

Kebiasaan merokok pada kaum remaja sangat terkait dengan pergaulannya dan kurangnya pengetahuan, pada umumnya ingin sekali diterima oleh kelompok seusia dan tidak ingin merasa kurang cocok. Beberapa alasan yang diberikan adalah merokok merupakan suatu hal yang dilakukan oleh orang dewasa, jadi orang yang merokok tampaknya lebih matang. Merokok dianggap bergaya, dari gambar-gambar bintang pop dan film. Selain itu, orang dewasa yang melambangkan 'otoritas' sehingga remaja menganggap bahwa merokok merupakan cara untuk mengungkapkan penentangan dan kemandirian. Alasan lain mengapa remaja merokok adalah adanya pendapat bahwa merokok menimbulkan rasa santai dan merupakan cara untuk mengatasi stres (Andika Sulistiawan, $2010: 3$ ).

Bila seseorang merokok, maka asap tembakau dihisap, karbon monoksida dan nikotin mengalir kedalam aliran darah dengan cara yang seperti oksigen lalu dialirkan keseluruh tubuh. Merokok mengganggu kerja paru-paru yang normal karena hemoglobin lebih mudah membawa karbon dioksida daripada membawa oksigen. Jika terdapat karbon dioksida didalam paru-paru, maka ia akan dibawa oleh hemoglobin dan tubuh memperoleh pasokan oksigen yang kurang dari biasanya. Itulah yang sering membuat perokok terengah-engah ketika melakukan pekerjaan yang berat. Otot mereka tidak memperoleh jumlah oksigen yang diperlukan untuk bekerja dengan benar sehingga mereka kehabisan napas dan berusaha mendapat lebih banyak udara. (Umi Istiqomah, 2003 : 20)

Nikotin yang terbawa dalam aliran darah dapat mempengaruhi berbagai bagian tubuh. Misalnya mempercepat denyut jantung dan menurunkan suhu kulit karena penyempitan pembuluh darah. Namun nikotin juga dapat berpengaruh menenangkan atau membuat perasaan lebih waspada, dan inilah yang sering dicari para perokok. Karena nikotin bersifat adiktif atau menyebabkan kecanduan, maka tubuh perokok yang sering membutuhkan nikotin jika tidak merokok tubuh terasa tidak enak. (Umi Istiqomah, 2003: 21).

Walaupun pemerintah sudah melakukan berbagai upaya terhadap 
masalah merokok, antara lain memberi peringatan langsung kepada konsumen dengan menuliskan pada setiap bungkus "Merokok daapat menyebabkan kanker, serangan jantung, impotensi, dan gangguan kehamilan dan janin" penetapan kawasan tanpa rokok seperti di sekolah-sekolah, iklan-iklan bahayanya merokok, peringatan para guru-guru dan para orangtua, namun kenyataannya perokok remaja itu masih banyak. Para perokok remaja menghisap rokok sambil nongkrongnongkrong, sambil jalan-jalan, dalam bis-bis walaupun disitu telah tertulis "Dilarang Merokok".(Umi Istiqomah, $2003: 5)$

Dari data di atas, diketahui bahwa beberapa pandangan atau pemahaman tentang merokok yang kurang tepat dari para pelajar. Pada dasarnya setiap orang atau pelajar tahu akan bahaya merokok mengingat di setiap bungkus rokok terdapat peringatan pemerintah tentang bahaya merokok bagi kesehatan.

Dari latar belakang diatas peneliti tertarik melakukan penelitian tentang hubungan tingkat pengetahuan siswa putra kelas I dan II tentang bahaya merokok terhadap perilaku merokok di SLTP Negeri 4 Sungai Penuh.

\section{KAJIAN PUSTAKA}

Menurut Notoatmodjo (2012 : 138) Pengetahuan merupakan hasil dari tahu, dan ini terjadi setelah orang melakukan pengindraan terhadap suatu objek tertentu. Pengindraan terjadi melalui pancaindra manusia, yakni indra penglihatan, pendengaran, penciuman, rasa dan raba. Sebagian besar pengetahuan manusia diperoleh melalui mata dan telinga.
Menurut Meylytiachrysty Tulenan (2015 : 4) perilaku merokok merupakan tingkah laku seseorang yang di mulai dengan membakar sebatang rokok yang terdiri dari bahan baku kertas, tembakau dan cengkeh terkandung nikotin dan tar kemudian menghisap asap yang berasal dari pembakaran rokok tersebut kemudian masuk kedalam paru-paru. Dan semakin banyak jumlah rokok yang dihisap setiap hari, maka semakin berat pula tingkah laku merokok seseorang

\section{METODE PENELITIAN}

Penelitian ini menggunakan desain Deskriptif Analitik yang bertujuan mencari hubungan antar variabel yang sifatnya bukan hubungan sebab akibat, biasanya dilakukan penelitian secara deskriptif terlebih dahulu untuk mencari data dasarnya. Pendekatan yang digunakan dalam penelitian ini adalah Cross Sectional, yaitu menggambarkan keseluruhan variabel yang diteliti dengan tujuan mengetahui tingkat pengetahuan siswa putra kelas I dan II tentang bahaya merokok terhadap perilaku merokok di SLTP Negeri 4 Sungai Penuh

Populasi adalah keseluruhan objek penelitian yang akan diteliti (Notoatmodjo, 2012:115). Sedangkan pada penelitian ini yang menjadi populasi adalah semua siswa putra kelas I dan II SLTP Negeri 4 Sungai Penuh dengan jumlah populasi sebanyak 149 orang.

Sampel adalah sebagian yang diambil dari keseluruhan objek yang diteliti dan dianggap mewakili seluruh populasi. Pengambilan sampel penelitian ini menggunakan teknik simple random sampling yaitu peneliti mengambil sampel dengan cara acak, 
pengambilannya dapat dilakukan lotre, akan tetapi pengambilannya diberikan nomor urut tertentu. (Notoatmodjo, 2012:120). Sampel dalam penelitian ini berjumlah 32 orang

Adapun etika penelitian menurut Hidayat (2011), dimana etika penelitian yang harus diperhatikan adalah sebagai berikut: Informed Consent kepada responden yang diteliti, peneliti menjelaskan maksud dari penelitian serta dampak yang mungkin terjadi selama dan setelah pengumpulan data. Anonymity Untuk menjaga kerahasiaan subjek maka dalam lembar pengumpulan data peneliti tidak mencantumkan nama tapi dibei kode, dan hanya diketahui oleh peneliti. Confidentiality Peneliti menjamin kerahasiaan informasi yang diperoleh dari responden. Semua informasi yang telah dikumpulkan dijamin kerahasiaannya oleh peneliti, hanya kelompok data tertentu yang akan dilaporkan dalam riset, dan data yang sudah tidak digunakan lagi akan dimusnahkan. Teknik pengumpulan data
peneliti mengumpulkan data primer dan data sekunder: dengan menggunakan kuesioner, informed consent dan wawancara. Kuesioner merupakan sejumlah pertanyaan tertulis yang digunakan untuk memperoleh informasi dari responden. Kuesioner yang digunakan adalah pertanyaan terstruktur untuk mengambil data tentang perilaku merokok. Data sekunder didapatkan berdasarkan sumber data dari SLTP Negeri 4 Sungai Penuhl.

Pengolahan data pada penelitian ini mulai dengan (Editing) pengecekan dan perbaikan isian kuisioner dilanjutkan dengan pemberian code setelah semua data diedit atau disunting, selanjutnya dilakukan pengkodean atau coding, yakni mengubah data berbentuk kalimat atau huruf menjadi data angka atau bilangan. Selanjutnya dengan penskoringan dimana peneliti memberi skor untuk masing masing pertanyaan dan selanjutnya memasukkan data yang sudah dilakukan pengkodean kedalam program komputer SPSS dan dilanjutkan Tabulating atau Memasukkan data dari hasil penelitian ke dalam tabel-tabel sesuai kriteria dan terkahir di cleaning.

Uji validitas merupakan alat ukur dan isntrument penelitian yang dapat diterima, sesuai standar untuk mengetahui validitas suatu instrument (dalam hal ini kuesioner). Dikatakan valid bila skor variabel tersebut berkolerasi secara signifikan dengan skor totalnya, dengan keputusan apabila $r$ hitung $\geq r$ tabel berarti valid demikian sebaliknya, jika nilai $r$ hitungnya $\leq r$ tabel tidak valid (Hidayat, 2013 : 93).

Instrumen yang digunakan dalam penelitian ini adalah kuesioner. Kuesioner diujikan pada selain responden, yang memiliki karakteristik hampir sama dengan responden yang akan diteliti maka MTsN Hamparan Rawang sebagai tempat uji validitas, berdasarkan uji validitas pada 20 responden yang telah dilakukan. Dari hasil uji validitas, diperoleh nilai $r$ hasil dari 16 pernyataan $>r$ tabel. Nilai $r$ tabel $(0,444)$. Dari hasil uji validitas pengetahuan dengan 17 pernyataan mempunyai nilai $r$ hasil $(0,479-0.976)$ dan perilaku merokok dengan 1 pernyataan mempunyai nilai $r$ hasil $(0,658)>$ dari $r$ tabel $(0,444)$, sehingga didapatkan pernyataan yang valid, sehingga instrumen dinyatakan valid. 
Reliabilitas adalah suatu ukuran yang menunjukkan sejauh mana hasil pengukuran tetap konsisten bila dilakukan pengukuran dua kali atau lebih terhadap gejala yang sama dan dengan alat ukur yang sama. Pertanyaan dikatakan reliabel jika jawaban seseorang terhadap pertanyaan adalah konsisten atau stabil dari waktu ke waktu. Jika pertantanyaan tidak valid, maka pertanyaan tersebut dibuang. Pertanyaan- pertanyaan yang sudah valid kemudian baru bersama-sama diukur reliabilitasnya. Untuk mengetahui reliabilitas dilakukan dengan cara melakukan uji Crombach Alpha keputusan uji : bila Crombach alpha $\geq 0,6$ artinya variabel reliabel, bila Crombach Alpha $<0,6$ artinya variabel tidak reliabel (Susanto, 2007:54)Dari uji reliabilitas, didapatkan nilai $r$ alpha/crombach's Alpha pengetahuan bahaya merokok $(0,763)$ dan didapatkan nilai Crombach Alpha perilaku merokok $(0,790)$ lebih besar dari konstanta 0,6 sehingga 16 pernyataan di atas dinyatakan reliabel.

HASIL PENELITIAN

Tabel 1. Distribusi frekuensi karakteristik umur responden siswa putra kelas I dan II SLTP Negeri 4 Sungai Penuh

\begin{tabular}{cccc}
\hline Kelas & Umur & Frekuensi (f) & Presentase (\%) \\
\hline I & 12 & 3 & 9,4 \\
& 13 & 11 & 34,4 \\
II & 14 & 16 & 50,0 \\
& 15 & 2 & 6,3 \\
\hline & jumlah & 32 & 100,0 \\
\hline
\end{tabular}

Dari tabel 1 dapat dilihat bahwa siswa putra kelas I dan II berdasarkan umur 14 tahun $(50,0 \%), 13$ tahun $(34,4 \%), 12$ tahun $(9,4 \%), 15$ tahun $(6,3 \%)$. Jika dilihat dari tabel diatas berdasarkan karakteristik umur yang banyak menjadi responden adalah berumur 14 tahun dan yang menjadi responden dari kelas I sebanyak 14 responden dan kelas II sebanyak 18 responden.

Analisa Univariat

Tabel 2. Disribusi frekuensi Pengetahuan tentang bahaya merokok pada siswa putra kelas I dan II SLTP Negeri 4 Sungai Penuh

\begin{tabular}{ccc}
\hline Pengetahuan & Frekuensi (f) & Presentase (\%) \\
\hline Tinggi & 12 & 37,5 \\
Rendah & 20 & 62,5 \\
\hline Jumlah & 32 & 100,0 \\
\hline
\end{tabular}

Dari tabel 2 dinyatakan bahwa pengetahuan pada penelitian ini terdiri pengetahuan tinggi dan rendah. Hasil penelitian ini menunjukkan bahwa responden yang pengetahuan rendah adalah sebanyak 20 orang $(62,5 \%)$ dan pengetahuan tinggi sebanyak 12 orang $(37,5 \%)$. 
Tabel 3. Disribusi frekuensi Perilaku merokok pada siswa putra kelas I dan II SLTP Negeri 4 Sungai Penuh

\begin{tabular}{ccc}
\hline Perilaku & Frekuensi (f) & Presentase (\%) \\
\hline Merokok & 27 & 84,4 \\
Tidak Merokok & 5 & 15,6 \\
\hline Jumlah & 32 & 100,0 \\
\hline
\end{tabular}

Dari tabel 3 dinyatakan bahwa perilaku merokok pada penelitian ini terdiri dari merokok dan tidak merokok. Hasil penelitian ini menunjukkan bahwa responden yang merokok sebanyak 27 orang $(84,4 \%)$ dan responden yang tidak merokok sebanyak 5 orang $(15,6 \%)$.

Analisa Bivariat

Tabel 4. Hubungan Pengetahuan bahaya merokok dengan perilaku merokok siswa putra kelas I dan II SLTP Negeri 4 Sungai Penuh

\begin{tabular}{|c|c|c|c|c|c|c|c|c|}
\hline \multirow[t]{3}{*}{ Perilaku } & \multicolumn{4}{|c|}{ Tingkat pengetahuan } & \multirow{2}{*}{\multicolumn{2}{|c|}{ Total }} & \multirow[t]{3}{*}{$\mathrm{p}$} & \multirow[t]{3}{*}{ OR } \\
\hline & \multicolumn{2}{|c|}{ Rendah } & \multicolumn{2}{|c|}{ Tinggi } & & & & \\
\hline & $F$ & $\%$ & $f$ & $\%$ & $\begin{array}{c}\text { jumla } \\
h\end{array}$ & $\%$ & & \\
\hline Merokok & 20 & 74,1 & 7 & 25,9 & 27 & $\begin{array}{c}100, \\
0\end{array}$ & $\begin{array}{c}0,00 \\
4\end{array}$ & 7,000 \\
\hline $\begin{array}{c}\text { Tidak } \\
\text { merokok }\end{array}$ & 0 & 0,0 & 5 & $\begin{array}{c}100 \\
0\end{array}$ & 5 & $\begin{array}{c}100, \\
0\end{array}$ & & \\
\hline Jumlah & 20 & & 12 & & 32 & $\begin{array}{c}100, \\
0\end{array}$ & & \\
\hline
\end{tabular}

Pada tabel 4. dari 32 responden dengan tingkat pengetahuan rendah cenderung merokok yaitu 20 orang $(74,1 \%)$ lebih besar dibandingkan dengan responden yang pengetahuan tinggi yaitu 7 orang $(25,9 \%)$. Dengan menggunakan analisa Bivariat dengan hasil uji statistik diperoleh nilai pvalue $=0,004$ $(\leq 0,05)$ maka dapat ditarik kesimpulan bahwa terdapat hubungan yang bermakna antara pengetahuan bahaya merokok terhadap perilaku merokok di SMP Negeri 4 Sungai Penuh. Dari hasil analisis juga diperoleh nilai OR (Odss Ratio) $=7,000$ artinya responden dengan pengetahuan rendah mempunyai peluang 7,000 kali lebih beresiko mengalami perilaku merokok dibandingkan dengan responden yang pengetahuan tinggi. 


\section{PEMBAHASAN}

Pengetahuan tentang bahaya merokok pada siswa putra kelas I dan II SLTP Negeri 4 Sungai Penuh

Dari hasil penelitian menunjukkan bahwa di SLTP Negeri 4 Sungai Penuh sebagian besar 62,5\% Siswa pengetahuan rendah tentang bahaya merokok. Berdasarkan analisis kuesioner responden yang pengetahuan rendah adanya ketidaktahuan responden tentang bahaya merokok karena responden tidak pernah/jarang mendapatkan promosi kesehatan tentang bahaya merokok.

Pengetahuan atau ranah kognitif merupakan domain yang sangat penting dalam membentuk tindakan seseorang (overt behaviour). Semakin baik pengetahuan siswa maka semakin baik tindakan dan perilakunya.

Hal ini tidak sama dengan penelitian yang dilakukan oleh Afdol

Perilaku merokok siswa putra kelas I dan II SMP Negeri 4 Sungai Penuh

Dari hasil penelitian didapat hampir seluruh siswa 84,4\% merokok. Perilaku merokok adalah perilaku yang membahayakan kesehatan baik bagi perokok sendiri maupun orang lain yang kebetulan menghisap asap rokok tersebut, namun kenyataannya dari hari ke hari semakin banyak orang yang merokok (Maya Aryani 2014 : 3)

Hal ini di dukung oleh penelitian yang dilakukan oleh Harsa Tri Pradana (2014) yang berjudul hubungan antara pengetahuan, sikap dan perilaku remaja tentang merokok di program studi ilmu keperawatan universitas muhammadiyah yogyakarta, hasil yang didapatkan
Rahmadani (2012) yang berjudul hubungan pengetahuan dan sikap terhadap rokok dengan kebiasaan merokok siswa SMP di kota padang, hasil yang di dapatkan bahwa responden yang memiliki pengetahuan rendah sebanyak 10 orang $(10,4 \%)$, dan pengetahuan tinggi 86 orang $(89,6 \%)$.

Hal ini sesuai dengan teori yang disebutkan oleh Notoatmodjo (2012) Pengetahuan siswa yang kurang akan bahaya merokok juga dipengaruhi oleh informasi yang didapatkan oleh siswa tentang bahaya merokok. Pengetahuan merupakan hasil dari tahu, dan ini terjadi setelah orang melakukan pengindraan terhadap suatu objek tertentu. Pengindraan terjadi melalui pancaindra manusia, yakni indra penglihatan, pendengaran, penciuman, rasa dan raba. Sebagian besar pengetahuan manusia diperoleh melalui mata dan telinga

perilaku kurang baik 39 orang (52\%) dan perilaku baik 36 orang (48\%).

Menurut Maya Aryani (2014) Perilaku merokok adalah perilaku yang membahayakan kesehatan baik bagi perokok sendiri maupun orang lain yang kebetulan menghisap asap rokok tersebut, namun kenyataannya dari hari ke hari semakin banyak orang yang merokok.

Menurut Notoatmodjo (2012) Perilaku hidup sehat adalah perilaku yang berkaitan dengan upaya atau kegiatan seseorang untuk mempertahankan dan meningkatkan kesehatannya atau pola/gaya hidup sehat mencakup tidak merokok dan mengendalikan stres. 
Hubungan tingkat pengetahuan siswa putra kelas I dan II tentang bahaya merokok terhadap perilaku merokok di SLTP Negeri 4 Sungai Penuh

Dari hasil penelitian menunjukkan bahwa persentase siswa putra kelas I dan II dengan pengetahuan tinggi cenderung mengalami perilaku tidak merokok sebesar $25,9 \%$, dan siswa putra kelas I dan II dengan pengetahuan rendah cenderung mengalami perilaku merokok 74,1\%.

Hasil uji statistik chi-square dengan derajat kemaknaan 95\% didapatkan nilai $\mathrm{p}<0,05$ atau $\mathrm{p}=$ 0,004 artinya dapat ditarik kesimpulan bahwa ada hubungan antara pengetahuan dengan perilaku merokok di SMP Negeri 4 Sungai penuh tahun 2017. Hal ini dapat dibuktikan dari jawaban responden bahwa lebih dari separoh responden yang pengetahuan rendah memiliki perilaku merokok serta hanya sedikit responden yang pengetahuan tinggi memiliki perilaku merokok.

Hasil penelitian ini sama dengan penelitian yang dilakukan Wahyu Kuntara (2012) yang menyatakan ada hubungan antara tingkat pengetahuan dengan perilaku merokok dengan nilai $p=0,001$. Hal ini juga dibuktikan dari hasil penelitian yang dilakukan oleh ratri setianingrum (2009) yang juga mengatakan bahwa ada hubungan yang bermakna antara tingkat pengetahuan dengan perilaku merokok dengan nilai $\mathrm{p}=0,000$.

Notoatmodjo (2012) mengatakan pengetahuan merupakan hasil dari tahu, dan ini terjadi setelah orang melakukan pengindraan terhadap suatu objek tertentu. Pengindraan terjadi melalui pancaindra manusia, yakni indra penglihatan, pendengaran, penciuman, rasa dan raba. Sebagian besar pengetahuan manusia diperoleh melalui mata dan telinga. Pengetahuan siswa yang kurang akan bahaya merokok juga dipengaruhi oleh informasi yang didapatkan oleh siswa tentang bahaya merokok.

Tingkat Pengetahuan Tahu (Know), Memahami (comprehension), Aplikasi (aplication), Analisis (analysis), Sintesis (syntesis), Evaluasi (evaluation) Menurut (Notoatmodjo 2012). Dilihat dari kategori tingkatan pengetahuan responden yang diteliti dimana lebih dari separoh responden memiliki tingkat pengetahuan rendah, maka dapat kita simpulkan bahwa pengetahuan responden di SMP Negeri 4 Sungai Penuh hanya sebatas tahu saja, artinya responden mengetahui tentang bahaya merokok namun belum mamahami apa itu bahaya merokok yang sebenarnya sehingga banyak responden yang tidak mengaplikasikan pengetahuan mereka.

Menurut Istiqomah (2003)

Rokok adalah hasil olahan tembakau terbungkus termasuk cerutu atau bentuk lainnya yang dihasilkan dari tanaman Nicotiana tabacum. Serta lebih dari separoh responden mengetahui bahwa rokok berasal dari olahan tembakau.

Menurut Maya Aryani (2014) perilaku merokok merupakan suatu fenomena yang muncul dalam masyarakat, dimana sebagian besar masyarakat sudah mengetahui dampak negatif merokok, namun bersikeras menghalalkan tindakan merokok. Menurut Notoatmodjo (2012) Perilaku hidup sehat adalah perilaku yang berkaitan dengan upaya atau kegiatan seseorang untuk mempertahankan dan meningkatkan kesehatannya atau 
pola/gaya hidup sehat mencakup tidak merokok dan mengendalikan stres.

Menurut asumsi peneliti bahwa tingkat pengetahuan rendah dapat mempengaruhi perilaku merokok yang kurang baik, dimana pada penelitian ini diperoleh hasil bahwa peluang

\section{KESIMPULAN}

Sebagian besar responden memiliki pengetahuan rendah tentang bahaya merokok di SLTP Negeri 4 Sungai Penuh tahun, Setengah responden memiliki perilaku merokok di SLTP Negeri 4 Sungai Penuh, Ada

DAFTAR PUSTAKA

Afdol, R. (2012). Hubungan Pengetahuan Dan Sikap Terhadap Rokok Dengan Kebiasaan Merokok Siswa SMP Di Kota Padang.

Andika Sulistiawan (2010) "Hubungan Tingkat Pengetahuan Remaja Tentang Efek Rokok Terhadap Kesehatan Dengan Sikap Merokok Di Sltp N 2 Grogol Sukohajo". Surakarta: Salemba Medika.

Ali, M. (2015). "tingkat pengetahuan tentang bahaya merokok pada siswa kelas $v$ sd negeri pucung lor 02 kecamatan kroya kabupaten cilacap tahun pelajaran 2014/2015".

Atikah dan Eni (2012) "Perilaku Hidup Bersih dan Sehat". Jakarta : Nuha Medika Awaloedin. (2010). "Majalah Keperawatan". Bandung: Fakultas IImu Keperawatan siswa dengan tingkat pengetahuan rendah 7,000 kali lebih beresiko mengalami perilaku merokok kurang baik dibandingkan siswa yang memiliki pengetahuan tinggi. Sehingga siswa harus diberikan penyuluhan yang baik tentang bahaya merokok.

hubungan antara tingkat pengetahuan siswa putra kelas I dan II tentang bahaya merokok dengan perilaku merokok di SLTP Negeri 4 Sungai Penuh.
Universitas Padjajaran Bandung.

Gigih, F. H. (2013). Bahaya Merokok Bagi Kesehatan. Semarang.

Harsa, T. P. (2014). "Hubungan Antara Pengetahuan, Sikap Dan Perilaku Remaja Tentang Merokok Di Program Studi Ilmu Keperawatan Universitas Muhammadiyah Yogyakarta".

Hidayat, A. A. (2013). "Metodologi Penelitian Keperawatan dan Teknik Analisa Data". Jakarta : Salemba Medika

Maya, A. (2012). "Hubungan Antara Sikap Terhadap Kesehatan Dengan Perilaku Merokok Di SMA Negeri 1 Pleret Bantul"

Meylytiachrysty, T. (2015). "hubungan perilaku merokok dengan prestasi belajar pada remaja perokok di SMA Negeri 1 Remboken" 


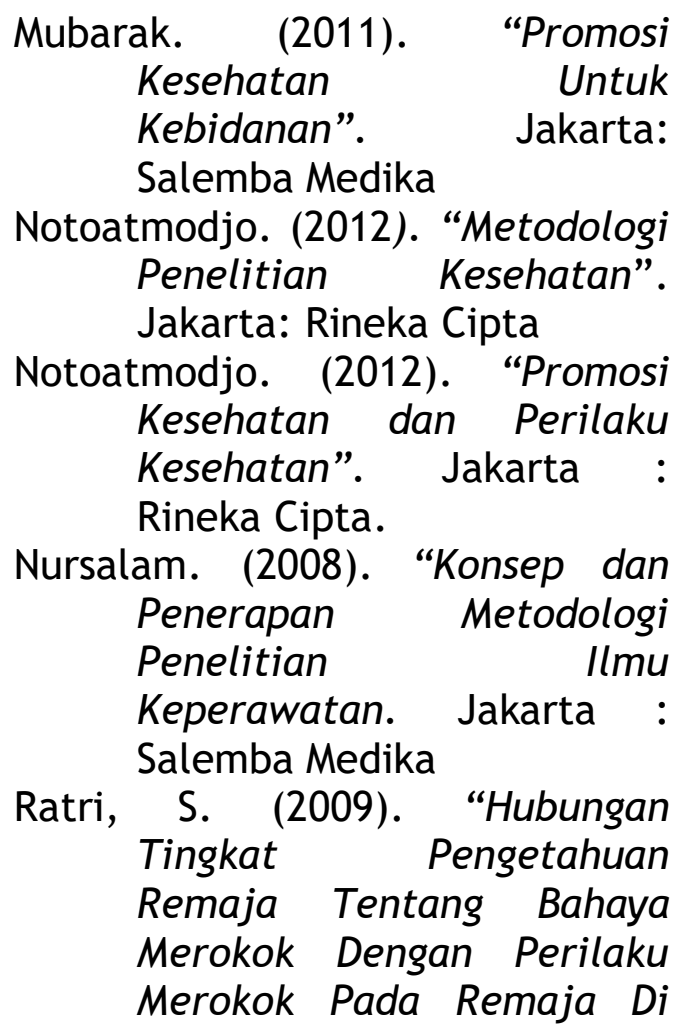

Desa Boro Wetan Kecamatan Banyu Urip Purworejo"

Riset Kesehatan Dasar. (2010). http: / /www.jambiupdate.c o/artikel-ini-dia-daerah-dijambi-dengan-jumlahperokok-tertinggi.html

Sudarsono. (2012). "Kenakalan Remaja”. Jakarta : Rineka Cipta.

Sutanto. (2007). "Metodologi Penelitian". Jakarta :UI

Umi, Istiqomah. (2003). "Upaya Menuju Generasi Tanpa Merokok" urakarta : Seti Aji

Wahyu, K. (2012). "hubungan antara tingkat pengetahuan penyakit akibat merokok dengan perilaku merokok pada usia dewasa awal di desa kacangan kecamatan andong kabupaten boyolali" 